\title{
THE "BALL OF CONFUSION" IN FEDERAL BUDGETING: A SHADOW AGENDA FOR DELIBERATIVE REFORM OF THE BUDGET PROCESS
}

\author{
Roy T. Meyers \\ Professor of Political Science \\ Director, Sondheim Public Affairs Scholars Program \\ UMBC (University of Maryland, Baltimore County) \\ meyers@umbc.edu \\ Presented at the Friday plenary of the annual conference of the \\ Association for Budgeting and Financial Management, Chicago, IL, October 24, 2008
}

\begin{abstract}
The budget process is seriously flawed, but there is little prospect for its effective reform. Negative economic and political conditions could open the window for reform, but the excessive partisanship that helped create these conditions has also reduced the pool of institutionalists who could lead reforms. More important is confusion about which reforms might be most effective. Most proposed reforms would create more rules, but they will not work unless politicians commit to meeting the goals these rules are intended to support. Those commitments could be produced by deliberation over critical issues that have been neglected in recent discussions of budget process reform: how the process could support macroeconomic policy-making, how improved budget concepts could accurately measure finances and aid dealing with upcoming policy challenges, how reorganization could enable intelligent prioritysetting, and how the process could be better aligned with the constitutional sharing of powers and the electoral system.
\end{abstract}

Acknowledgments: Very helpful comments on an early draft were received from Jim Hearn, Phil Joyce, Rudy Penner, and Kathy Ruffing, who do not necessarily agree with the contents of the final version. The article is dedicated to the late Robert W. Hartman; his wisdom and humor are greatly missed. 
Many baby boomers will remember a popular song from 1970 called "Ball of Confusion (That's What the World Is Today)." Sung by the Temptations, its lyrics aren't great: they included the rhyming phrase: “Great googalooga, can't you hear me talking to you”! The song did include lines that are relevant to budgeting (e.g., "Politicians say more taxes will solve everything"), and expressed discontent which has returned to the political landscape (e.g., "People all over the world are shouting, 'End the war'”'). But what especially impressed then, and makes the song still relevant, was the song's rhythmic urgency; it evoked the concerns of people asking worried questions about the state of the world.

In a 2007 Public Administration Review article, Rubin expressed serious concerns about what she called the unraveling of the budget process. Hoagland (2007) responded by crediting the process with some successes that balanced the problems he acknowledged. This article argues that problems with the process are more serious than both acknowledged, that some problems with the budget process are due to confusion, and that effective budget process reform will require a deliberative process that seeks to reduce such confusion. I rush to clarify that I am not questioning the expertise of Rubin and Hoagland, who have made immense contributions to budgeting. Their prominence, though, makes their disagreements all the more striking, which can't be explained fully by their differing roles as academic and practitioner nor by their divergent ideological stances.

${ }^{1}$ By Normal Whitfield and Barrett Strong, Motown Records, complete lyrics at: http://www.oldielyrics.com/lyrics/the_temptations/ball_of_confusion_thats_what_the_world_is_t oday.html. 
$\underline{\text { Dead, or Just Pinin' for the Fjords? }}$

Most Americans have a pervasive sense that budget totals are now at imprudent levels.

Americans had the same feeling during the mid-1980s, when deficits hit their then post-WWII peak as percentage of gross domestic product. After Reagan's re-election, when an effort to slow entitlement spending growth failed, Congress resorted to the procedural absurdity of Gramm-Rudman-Hollings (GRH), which was described by one of its authors as a "bad idea whose time has come." Experience quickly confirmed that, indeed, bad ideas don't work. Then, deficit control procedures adopted in the 1990 Budget Enforcement Act (BEA) and the massive deficit reduction packages of 1990 and 1993 helped generate the budget surplus that appeared in 1998, with a substantial boost from extraordinary productivity growth. Medium-term projections unrealistically showed such big surpluses that the federal government might pay off its debt. Policy again turned: add the defense spending shock from 9/11 to the decision of Republican leaders to protect their majority status with "big government conservatism" (i.e., tax cuts financed by borrowing rather than by spending cuts), and then add the unknown budgetary effects of the financial crisis, and you arrive at our current situation.

While large projected deficits once focused attention on possible flaws in the budget process, that has not been the case recently. For example, the House Rules Committee held only five hearings on budget process issues in the last eight years, and none since 2005. One reason is that budget problems, while generally appreciated by Americans, have not been highly salient compared to a series of other issues. Consider the receptions received by budget hawks, epitomized by the "Fiscal Wake Up Tour," led by U.S. Comptroller General David Walker, 
accompanied by a panel of experts from conservative and moderate think tanks. ${ }^{2}$ While this tour may have slightly increased the public's awareness of fiscal risks, it did not force Presidential candidates to make policy proposals that would reduce deficits; they instead proposed policies that would do the opposite. One candidate, Mike Huckabee, an ordained minister, responded to criticism of this with: "Folks, I didn’t major in math. I majored in miracles."

Many Americans would indeed prefer painless miracles for expanded health care coverage, lower gas prices and taxes, and an end to the Iraq war over making real sacrifices for deficit reductions. Even the children of baby boomers, while resentful on the surface of supposed intergenerational inequities, do not act as if projected deficits are important.(Buckley, 2007) The wonderful metaphors of Charles Schultze-where the risks of sustained deficits are not wolves at the door, but rather termites in the basement-are consistent with most Americans' embrace of "out of sight, out of mind.”(1989)

If the best animal metaphor for budget policies is termites, then a comparable animal metaphor for the budget process may be a dead parrot. My apologies for another boomer cultural reference, which is to the Monty Python skit that begins with a customer saying to a pet store owner: "I wish to complain about this parrot what I purchased not half an hour ago from this very boutique." ${ }^{3}$ Fans of the skit know what happens next: the owner of the store (Michael Palin) tells the customer (John Cleese) that the (Norwegian blue) parrot is "just resting," or on second thought, "pinin' for the fjords." In fact, rigor mortis has set in, and the only reason poor Polly was standing on its perch when purchased was that it had been nailed there. As Palin's denials of

\footnotetext{
${ }^{2}$ See http://www.concordcoalition.org/events/fiscal-wake-up/index.html

${ }^{3}$ See http://www.mtholyoke.edu/ ebarnes/python/dead-parrot.htm
} 
the obvious become even more absurd, Cleese loses his calm and indignantly shouts (with accent):

'E's passed on! This parrot is no more! He has ceased to be! 'E's expired and gone to meet 'is maker! 'E's a stiff! Bereft of life, 'e rests in peace! If you hadn't nailed him to the perch 'e'd be pushing up the daisies! 'Is metabolic processes are now 'history! 'E's off the twig! 'E's kicked the bucket, 'e's shuffled off ' is mortal coil, run down the curtain and joined the bleedin' choir invisible!! THIS IS AN EX-PARROT! ${ }^{4}$

So: (1) is the budget process an "ex-budget process;" (2) is it "just resting;" or (3) is it still functioning adequately? In Washington, it is not impossible to find people who take all three positions--though on different days.

Senator Kent Conrad (D-ND), the chair of the Senate Budget Committee, is an example. When the Congress passed the FY09 budget resolution on June 5, Conrad claimed credit in a Senate Budget Committee press release:

We have clearly demonstrated Democrats' ability to govern. For the second year in a row with Democrats controlling Congress, we have passed a budget. This stands in stark contrast to previous Congresses. In fact, this is the first time since 2000 that Congress has adopted a budget during an election year. And even more important, this fiscal plan sets the nation back on a path of fiscal responsibility.

The resolution, at 122 pages long, is not easy to summarize, but it is easy to criticize. ${ }^{5}$

The bottom line to its supporters was that the resolution would return the budget to surplus in FY2012. It did so in part by assuming the expiration of tax cuts that many had pledged elsewhere to continue, and by neglecting to assume war funding that would soon be appropriated.

${ }^{4}$ I acknowledge that Dana Milbank of The Washington Post used the same skit for a biting sketch of Hillary Clinton's refusal to acknowledge she had lost the Democratic nomination for President, but I have used this comparison to the federal budget process for several years.

${ }^{5}$ That's not unusual; the Senate Budget Committee Republican staff's Budget Bulletin confessed on March 13, 2008 that "the content of an actual budget resolution is notoriously useless for almost any user." 
Congress wanted higher discretionary appropriations than did President Bush, yet it was widely known when the budget resolution passed that the Congress would wait to enact most appropriations bills until the president vacated office, nearly four months after the start of the fiscal year. The resolution's sponsors also claimed that the budget would allocate more funds to very specific high priorities, such as home energy assistance and Head Start, even though there has never been a procedure to force the Appropriations committees to fund programs consistent with such recommendations. The resolution also included numerous "reserve funds," purporting to allow even more spending for specified purposes if offsets to the costs could be found, which was about as likely as Gov. Huckabee's miracles.(Baumann, 2008)

But leading up to this budget resolution, Senator Conrad had advocated for a Bipartisan Task Force for Responsible Fiscal Action, introduced in 2007 with Senator Gregg. Chaired by the Secretary of the Treasury, with another member from the administration (presumably the OMB Director), the remaining 12 members would be an equal number of Senators and Representatives and of Democrats and Republicans. They would be asked to report by December 2008 legislative recommendations for deficit reduction, but these would be put before the Congress only if supported by at least 12 members. Their recommendations would be considered on a fast-track, but a three-fifths majority in each body would be required for passage.

In sum, Conrad's position was first that the budget process is an "ex-budget process," and then that it wasn't; apparently the change of mind was produced by some harsh reactions by colleagues to the proposed Task Force. But with the Conrad-Gregg proposal, at least he was acknowledging problems with the process. Why haven't more legislators been doing the same?

Many, busy advocating for favored causes, lack the time, interest, and position to become 
"budget process junkies." Those few who do may learn that some oft-proposed alternatives (e.g., a constitutional amendment for a balanced budget) would worsen the process (i.e., by setting an unreasonably fixed target and by adding the unwieldy judicial branch to an already overly complicated process). Political realists also understand that Congress is an exceptionally traditionalist institution.

But perhaps the strongest explanation is that the current process is functional for the many elected officials who greatly value extreme partisan conflict. In recent decades, partisan behavior among elites has returned to the high levels of a century ago; this trend coincidentally began roughly about when the Congressional Budget Act (CBA) was adopted.(McCarty, et. al., 2006) Now the majority attempts to make all decisions without involving the minority, and claims credit for the supposedly positive results. While this relegates the minority, especially in the House, to being bit players, at least they can blame the majority for anything bad in hopes of reversing their minority status at the next election, which will come very soon. Neither side has a strong incentive to instead start cooperating, because it is likely that the other side will take advantage of the first mover's unilateral disarmament.(Gilmour, 1995) Rubin may have been especially thinking of this when she wrote that "It is not so much that we do not know what reforms are likely to work, but that we do not know how to motivate those who benefit from the status quo to adopt and implement the necessary reforms.”(2007, p. 615)

\section{$\underline{\text { In Search of a Few Institutionalists }}$}

It may be, though, that this assessment is wrong, at least for predicting the future. Below this article suggests that we need to think much more about which budget process reforms might be 
preferable. But first it considers whether the budget process is ripe for reform.

While Congress is generally averse to change, periods of policy and institutional crisis can stimulate internal reforms.(Dodd, 1993; Mayer and Canon, 1999; Zelizer, 2004; Schlicker, 2001). Legislators reform then because they are losing individual power due to their branch's weakness. Passage of the CBA was enabled by public disapproval of the Congress that was due in part to late appropriations (we've got that covered now!), and by Presidential threats of Congressional prerogatives (check!--if signing statements are the equivalent of impoundments). The 1987 stock market crash set in motion the negotiations that eventually produced the BEA, implying that another stimulus for budget process reform is a weak economy joined with a financial sector crisis in which the government is implicated (roger!). Approval ratings for the Congress are now at historic lows (and are even below those for President Bush), and though budget failures are not the main cause, they are implicated (e.g., earmarks, war costs, inactivity enabled by numerous budget process veto points).

If then, in fact, the "window" is now open, needed next are policy entrepreneurs who will take on the status quo.(Kingdon, 1984) Are the Presidential candidates such advocates? After Senator DeMint's proposal to ban earmarks was defeated, Senator McCain said, "The last place where they don't get it is Washington, D.C." Senator Obama's "hope" and "change" rhetoric is often interpreted as "post-partisan"-or to rephrase a stance taken once by the incumbent, more uniting than dividing. While the claims of McCain and Obama both evoke much skepticism among Washington insiders, they nevertheless raise the slight possibility that Presidential leadership could assist budget process reform.

Significant reform will not occur, though, without a return of "institutionalists" to the 
Congress. By this term, I mean legislators who forgo actions that would bring temporary personal and partisan advantages but over the long run would hurt the institution. More positively, Congressional institutionalists work tirelessly to promote norms, and to design organizational structure and procedures, so that legislators can cooperate on policies as well as dispute them, in order to make decisions that are better for the country.(Heclo, 2006; Hamilton, 2004.) Many seasoned observers (e.g., Mann and Ornstein, 2006) have lamented the absence of such figures from today's Congress-leaders who would remind us of, say, Representative Bolling or Senator Dirksen. These leaders certainly engaged in partisan conflict, but they also practiced the art of compromise. Today's close partisan combat makes that much harder. ${ }^{6}$

\section{A Shadow Agenda and a Deliberative Process}

Imagine, though, that institutionalists will emerge to lead reforms. What should they advocate?

Answering this question well is a more complicated problem than many seem to

${ }^{6}$ Conrad's sponsor for the bipartisan task force, Sen. Gregg, previously proposed a very partisan approach to budget process reform-the Stop Over-Spending Act-which made Democrats wary. The SOS Act passed 12-10 in committee, but was never considered on the floor.

Republicans are similarly wary of House Appropriations Committee Chair Obey, whose reputation for support of budget process reforms has taken a hit because he has defended his committee against anti-earmark claims he views as being blown out of proportion. Republicans proposed 10 budget process reform amendments to FY09 the budget resolution in the House Budget Committee; all were defeated by party-line votes.

In a talk before Congressional staff during the spring of 2008, I asked for nominations of current institutionalists. The first was for Rep. Ray LaHood (R-IL), who in my opinion, fits the bill. However, my point was confirmed by the fact that LaHood had just announced his retirement, in part because of his frustration with excessive partisanship. 
appreciate. ${ }^{7}$ When budget process reforms have been proposed in recent years (e.g., see OMB, 2008; Committee for a Responsible Federal Budget, 2007; Riedl, 2005; CBO, 2004), the following usual suspects have been lined up:

1.More rules to prevent actions: caps on discretionary spending, sometimes with "firewalls" (separate caps for subsets); "pay-as-you-go" (PAYGO) to prevent tax or entitlement changes from increasing the deficit; sequestration to backstop these rules;

2. More rules to force actions: "triggers" to set spending ceilings for programs which when hit would require expedited consideration of changes (the "soft" approach) or would automatically revise those programs through reconciliation or executive actions ("hard"); triggers for the whole budget, with sequestration applied to direct spending; programs put on a schedule for automatic termination ("sunset") unless renewed by a commission; a commission would certify that programs delivered "results" to retain funding;

3. Increasing transparency: disclosing sponsors and beneficiaries of earmarks before consideration; publishing on the internet data on actual expenditures in a highly-specific format (e.g., location, purpose, beneficiary); and

4. Some very old chestnuts: shifting power toward the President by grant of a line-item veto; changing the budget process schedule from annual to biennial.

Many of these proposals have a return-to-the-past character-this is a problem when some seem to remember only the good part of the old days, such as viewing 1990 to 1998 as the

${ }^{7}$ On the other hand, it could be worse. The budget process reform agenda in the U.S. is much shorter than in many other countries because of the relative success we have had in dealing with essential tasks of budgeting. For example, few advocates in the U.S. argue for greater control of obligations and for higher quality audits of expenditures, for these functions are performed with quiet professionalism in most cases. 
"golden era" of the budget process and repressing memories of the government shutdowns of 1995-6. To avoid this problem, analysis of such proposals should carefully compare their pros and cons. For example, increased transparency for earmarks might enable enforcement of a ceiling on this spending, but the savings would be small, and transparency could also certify credit-claiming by earmark sponsors, creating pressure to increase the ceiling. Such analysis tries to reduce instrumental uncertainty--confusion about how policy actions might be enabled or constrained by the budget process.(Meyers, 1996; Joyce, 2008; 1996) Participants usually rely on historical precedents and on analogies to guess about these impacts, which can be difficult. Consider the problem faced by the Blue Dogs when they were asked to agree that offsets shouldn't be required for intended counter-cyclical policies: should they worry that this procedural exception would be exploited in the future for inappropriate purposes? On the one hand, discretionary caps held during much of the 1990s; on the other hand, Congress and the President treated the 2000 Census as an "emergency" that did not count against spending caps.

The question the Blue Dogs faced was about the efficacy of one budget process rule. What budget reformers need to do more generally is to ponder whether the significant accretion of rules since 1974 has helped or hindered the process.(Schick, 1980, 1990, 2007) While some of these rules have prevented evasions of budget controls (e.g., some scorekeeping agreements between $\mathrm{OMB}$ and $\mathrm{CBO}$ ), others have made the process more confusing (e.g., adjustments to discretionary caps for "program integrity" spending) or have not prevented gimmickry (e.g., effective date shifts). More rules have also slowed legislative action, a particularly worrisome problem in the Senate. In response to such delays, some advocates have proposed counterproductive workarounds, such as making the entire budget for veterans an advance 
appropriations.(Freedberg, 2008)

The main problem with budget rules is that too frequently they have been ignored or waived. Sometimes, the response to this is to make a rule "tougher" by adding more specificity or apparent legal force. OMB proposed to define "emergency" in the law with criteria such as: "sudden, which means quickly coming into being or not building up over time" and "temporary, which means not of a permanent duration." Perhaps this desire for clarity is understandable in a town where a President splits hairs on the meaning of "is" and Supreme Court justices pretend to take an abstract constitution literally. It does imply, though, that substantial parts of the dictionary must be incorporated into budget statutes, or that a textbook's description of basic mathematical operations must be cited in baseline rules. But even if that route is chosen it is likely to fail, for even Presidents have found it convenient to violate clearly-written OMB rules (e.g., on lease-purchases).

Of course, rules often don't fail because they are either too complicated or not complicated enough. Rather, rules fail because they are endogenous to the political institutions that wrote them, meaning that they can be changed, by de jure or de facto means, whenever the institutions want. Rules that would produce politically uncomfortable results are more likely to be changed. ${ }^{8}$ Consider the Democrats' recent experience with PAYGO rules. Generally weaker than earlier versions, and differing between the House and Senate, PAYGO has featured in many disputes over Medicare and Medicaid, the AMT patch and tax extenders, renewed benefits for farmers and new benefits for veterans, terrorism insurance and flood insurance--the list goes on

${ }^{8}$ See Primo, 2007, for an extensive review of the massive public choice literature on this subject. Though it provides valuable insights that historical analysis does not, this literature is still too reductionist to enable careful design of a better budget process. 
and on. Republicans and wavering Democrats, particularly in the Senate, have been unwilling to require offsets, practically eviscerating the newer PAYGO, and even the advocates of PAYGO have used accounting gimmicks to claim compliance. PAYGO seems to be promoting cynicism more than deficit reduction.(Gregg, 2008; Friel, 2008).

Wildavsky and Caiden would explain this situation by arguing that without normative support, budget rules will fail.(2004, p. 181) Unfortunately, how to use rules to promote norms is still a fundamental mystery in practice (witness the limited success of international development assistance for better "governance"). While rational institutionalists narrowly consider how normative commitments could be made credible by enforceable contracts (aka rules), the contrasting perspective of public administration is that normative agreement also involves a significant element of deliberation.(Hood and Jackson, 1991) There is no space here to summarize this broad literature, but its essence is that people should think about and discuss the implications of decisions before they act.(Cooke, 2000; Gutmann and Thompson, 1996)

The critical recommendation in this article is that such a deliberative process is needed to jump start the cause of successful budget process reform. That is because the reform agenda outlined above does not confront underlying problems that prevent budget process success. The remainder of this article briefly identifies four such problems: the lack of a clear connection between budgeting and macroeconomic policy-making; budget concepts that neither accurately reflect financial transactions nor help the country address looming policy challenges; the unsuitability of current jurisdictions and budget categorizations to support intelligent prioritysetting; and the delay and conflict that epitomizes budgetary relationships within the Congress and between the Congress and the Presidency. 
These problems must be addressed not only because they are central to budgeting, but because they were not solved in 1974 . The CBA, like almost all legislation, was a compromise that reflected the policy concerns and political pressures of that era. What Rubin identifies with her metaphor of "unraveling" was entirely predictable-as time uncovered dramatic changes in partisan politics and surprising policy dilemmas, the patched quilt of the budget process suffered worse wear than fraying a bit at its edges. It's time to sew a new one-to refound the budget process.

Given space constraints and my own confusions, the article does not recommend exactly how to do this. Instead, the approach is to provide a "shadow" agenda, as would a loyal opposition, for budget process reform. This agenda could be used by a budget process reform commission which could study these problems, and then recommend changes that politicians could then consider and modify. Some significant and positive changes to the U.S. budget process have been generated using this approach (Cleveland, Brownlow, Hoover (twice), President's Commission on Budget Concepts); significant innovations in budgeting by Westminster countries have also been informed by deliberative processes.(Rubin and Kelly, 2006)

This suggestion is very different from the action-forcing commission, task force and trigger proposals included in the above list of reforms. Their proponents assume that the process is so broken that reform is not possible; rather, elected officials must be convinced to bind themselves to the mast. They cite as evidence in support of this approach the base realignment process, while minimizing lessons that should be drawn from the more appropriate comparisons to Gramm-Rudman-Hollings and to Medicare's Sustainable Growth Rate, both of which failed to 
produce intended results .(See Brookings/Heritage, 2008, and Penner and Steuerle, 2005 for positive views on this approach, and Aaron, et. al., 2008, and Greenstein, 2008 for negative ones.) Paradoxically, even though the action-forcing approach gives up on the traditional form of representative democracy, some supporters of this approach also claim that it would engender cross-branch and cross-aisle trust, thus enabling the Congress and the President to make the existing budget process work, warts and all. Some sponsors have even used the term "confidence building," reminiscent of the Middle East peace process. The comparison is apt in that it may take a higher power than Governor Huckabee for such a budget miracle!

It would be smarter to hope instead for compromises, ones in which the potential components of a better budget process are analyzed by skilled practitioners and academics, and then negotiated into a new design by the elected officials who are constitutionally responsible for governing.

\section{Budget Totals and Dead Armadillos}

One of the disputes between Rubin and Hoagland was whether the budget process is supposed to be "neutral" with regard to budget totals, or biased towards the prevention of deficits. The liberal populist Jim Hightower once wrote a funny book titled “There's Nothing in the Middle of the Road But Yellow Stripes and Dead Armadillos" that is relevant to this dispute.(1997) He warned Democrats that moderation was no virtue; instead, it invited being run over, as happens to armadillos who try the middle of the road. (A promise: this will be the last animal metaphor.) Similar arguments have been made by more authors from the right to describe the small government/low tax ideals of Republicanism, and especially recently, to excoriate Republican 
leaders for their impure attraction to big-government conservatism.

Budget process "neutrality" has been an attractive rationale to politicians on both sides of the aisle who prefer to avoid the fate of brave armadillos. Many Republicans played to their base by pledging to never increase taxes, and many Democrats promised to never cut priority spending. While budget hawks can explain this behavior, they don't excuse it. They want the budget process to be biased towards deficit reduction, rather than permitting a "neutrality" that would guarantee the opposite.

At the end of a previous period when deficit-promoting "neutrality" held sway, Herb Stein wrote:

Discussion of federal budget policy in the United States has fallen to an abysmally low level. It consists wholly of bumper-sticker slogans, sound bits, lip reading. It finds public expression in shibboleths like no new taxes, balance the budget, don't raid Social Security. Prescriptions for dealing with the budget evade the central problem, which is making choices.(1989a, p. 16)

If this sounds familiar, thus suggesting a positive correlation with periods of fiscal leniency, let's review the "golden era" of deficit reduction. After Bush the Prudent capitulated to his best instincts in 1990, the right wing in his party helped bring him down for raising taxes. Clinton won the Presidency while promoting fiscal stimulus, and then turned on a dime to govern by drawing from the budget hawk policies of two candidates he defeated (Tsongas and Perot). The policy success of that approach brought a new political challenge when the surplus appeared-Republican demands for large tax cuts. Clinton responded, true to form, with an electorally-oriented tactic-he "saved Social Security first," declaring the trust fund cash flow surpluses to be off-bounds. Then his Vice President repeated to the point of being ridiculed that he would protect these funds with a "lockbox." That is, the administration failed to educate the 
public about the possible benefits of building debt capacity. This helped Bush the Imprudent enact massive tax cuts, which when combined with other budget policies created the largest fiscal stimulus in the nation's history.(Steuerle, 2007, p. 13). Assuming the revelations of Paul O'Neill are accurate, the Bush administration did so with a remarkably confused understanding of macroeconomic ideas.(Suskind,2004)

A final anecdote in this mini-history relates to Keynes' observation that we are often the slaves of a defunct economist. Today he might complain that recently we are the slaves of a very alive economist, and a central banker at that: Alan Greenspan. While Greenspan reacted in horror about threats to the Fed's independence from legislators' suggestions about monetary policy, he quickly offered opinions about fiscal policy when importuned by legislators, who hoped to gain opaquely-stated support for the budgetary policies they advocated. The risks of this interaction for the system were shown when Greenspan intentionally allowed his cautious warning about the rapid progress on debt repayments to rationalize large tax cuts.(Kuttner, 2004)

How did the Fed Chair become an oracle? In part, he filled the vacuum left by the weakness of two executive branch economic policy institutions: the Council of Economic Advisors (CEA), and in the Bush administration, the OMB, whose Directors after Mitch Daniels were less visible than the "at an undisclosed location" Vice President, and less feared as well. Under the framework established by the Employment Act of 1946 and Humphrey-Hawkins Act of 1978, these institutions are charged with integrating and explaining macroeconomic and budgetary policies. According to authorities like Nobel laureate Joseph Stiglitz, CEA and OMB

${ }^{9}$ The ironies are numerous. Now Greenspan's Fed is blamed for enabling asset bubbles that will lead to heavy fiscal costs. His successor was generally unwilling to comment on the details of budget policy, but was forced to make the Fed the "guarantor of last resort." 
have been supplanted by the White House's National Economic Council, an instrument of the permanent campaign. ${ }^{10}$ In Congress, the Joint Economic Committee, similarly charged by statute with macroeconomic policy-setting, has long been unable to deliver. If the budget committees once filled that vacuum, they do no longer, as budget resolutions fail to provide convincing rationales for their totals.

But budget totals do have effects: on the government's financial sustainability, on macroeconomic growth and stabilization, on the balance of intergenerational equities, and so on. Understanding these effects is necessary if we are to have a budgetary norm of "balance" that is more than a meaningless abstraction. Therefore, a better budget process would feature robust institutions that would analyze, negotiate, and explain how the budget's "bottom line(s)" would affect macroeconomic conditions. The first task of a budget process reform commission should be to develop advice on this topic. It could consider whether the government should continue to use discretion to set budget totals, or whether it should adopt as guidance one of a variety of fiscal rules, such as a ceiling for public debt as a percentage of national income, the "golden rule" of a budget balanced over the business cycle, a target for budget surplus-driven national saving that could help finance future entitlement spending, or a deficit to finance public investment. It could also, as either an alternative or a complement to a fiscal rule, recommend how specific macroeconomic and budgetary institutions could improve their capacities and interactions.

Any commission discussion about these topics would necessarily require clarification of related budgetary accounting concepts. The next section addresses this issue.

${ }^{10}$ For economy policy histories, see Feldstein, 1994; Frankel and Orszag, 2002; Kopke et. al., 2007; Dolan, et. al., 2008; Orszag, Orszag, and Tyson, 2002 disagree with Stiglitz. 
$\underline{\text { Ticking Time Bombs and Federal Budget Concepts }}$

Military planners can be criticized for correcting past errors more than anticipating future problems. Many budget hawks argue that they have long avoided this "last war" mistake by focusing on future financial risks, which they believe are concentrated in Social Security, Medicare, and Medicaid. Despite their vigilance, defeat may be close at hand, as some boomers are now collecting early retirement benefits. The magnitude of that defeat could be quite large: when budget hawks peer into the future, they see entitlements expanding to equal total current government spending. Assuming that current non-entitlement spending and revenues are unchanged, the government would have to borrow excessively, which would crowd out private investment and throw the economy into a deep dive, or hand over ownership of the U.S. to foreigners. ${ }^{11}$

This "ticking time bomb" projection is substantially informed by the retrospectiveoriented financial reporting approach, which uses an accrual basis to value assets and liabilities. Recording in the budget the projected costs of future entitlement benefits when they were "earned" (through payment of dedicated taxes) could have formally warned of future obligations. However, the federal government uses this basis for budgeting only with a few programs, such as those that extend credit, even though agencies have now spent nearly two decades and massive amounts improving their ability to prepare accrual-based financial reports. ${ }^{12}$

${ }^{11}$ See, e.g., Kotlikoff and Burns, 2004. There are substantial reasons to question their proposed solutions, which focus excessively on reductions in entitlements; White, 2001.

12 Though not without problems. An example: GAO confessed that its attempted reconciliation between accrual and cash deficits by FY07 created a difference of $2 \%$ of revenue that could not be explained, though it gave the Statement of Social Insurance an unqualified opinion.(GAO, 2008, 2007) 
Why has the federal government shied away from requiring accruals for the largest entitlement programs? Using Social Security rather than health spending for the sake of simplicity, there are conflicting explanations. Since baby boomers have already earned many of their expected credits, accrual might be too late to have an effect. Others worry about the opposite effect, in that accrual could quickly force cuts, causing incumbents to be blamed by those who lost expected benefits. A third perspective is that accrual could certify that projected benefits had been earned, converting what are only semi-strong promises into iron-clad liabilities. A fourth concern is that uncertainties about the magnitude and timing of benefits are so great that accruals could foster such gaming that budgetary aggregates would be completely distorted.

Though the budget largely retains the cash basis for calculating budget totals, GAO's Walker talked up the different concept of "net operating cost" (which counts long-lived costs for federal employee retirement and the like, but not for Social Security, Medicare, and Medicaid), GAO (2007) also suggested that the government publish a long-term fiscal sustainability report, again separate from and different than the budget. Unlike the net operating cost calculation, it would include the unfunded costs of the big three entitlements, such as by estimating the "fiscal gap" (the immediate increase in taxes and/or cuts in spending necessary to make up a projected excess over time of outlays over revenues). That is, confusion over the budget's bottom line is now certified by the government's auditor.

Budget hawk presentations often try to cut through this confusion by extrapolating trends to develop future year point estimates of huge government debt, high "European tax rates," and much-smaller GDPs. They may be right, though a more reasonable projection would assume that politicians will react before it's too late to prevent catastrophes. 
On the other hand, budget hawks might be underestimating potential problems. Since the current financial crisis has been compared to that which started the Great Depression, you might try the following thought experiment: travel back 75 years from now (following the Social Security and Medicare actuaries)--that is, from 2008 to 1933. Ask yourself: what important things happened in the decade following 1933 that an intelligent person would not predicted? Now do the same for the next 65 years. It's a very long list. Now try the same for the 75 years after 2008-and by the way, best of luck. Donald Rumsfeld was wrong about much, but he was right that there are "unknown unknowns," and they will be important.(Taleb, 2007) Yet the "known unknowns" are now worrisome enough: restructuring the world's financial system; reducing national security threats; coping with pandemics; and adjusting to global warming.(Smil, 2008) None of these are recognized in the budget hawks' focus on the big three entitlements.

If the budget process is to help us deal with these challenges, then we need improved methods for measuring and reporting the costs of government actions. Current budget concepts are based on the 1967 President's Commission on Budget Concepts (PCBC) and on provisions of the Congressional Budget Act, as amended; budget agencies are continually required to revise and refine these concepts when confronted with new situations. The results are often confusing. Baseline projections, for example, when prepared according to the law's prescriptions, are widely viewed as unrealistic, forcing even budget agencies to develop alternative scenarios that seem more plausible. A more recent example of confusion was the reported $\$ 700$ billion cost of the Treasury "bailout" (or "rescue") plan. This plan presented immense difficulties to those who would project its cost. Treasury requested that its assistance be accounted for under the 
provisions of the Credit Reform Act, which attempts to measure the net cost of a government action using discounted cash flows, at times adjusted for risk. Of course, in this case the government was greatly expanding its role in the economy precisely because financial uncertainties made it impossible for private entities to reliably project likely risks and cash flows. While many economists argued that the Treasury's proposed auction process would encourage business to dump toxic assets on the government, many politicians were arguing that the asset exchanges would be costless (and therefore result in no net outlays even though they would increase the debt).

The financial crisis evolved in part because the government failed to accurately determine the scope of the budget-that is, what's properly counted and what's properly excluded. Early in the crisis the government effectively took control of Fannie Mae and Freddie Mac. These "government-sponsored enterprises" (GSEs) had used their ostensible private status to avoid budget scrutiny despite the huge financial risks they were imposing on the federal government. That is, budget concepts used a black- or white-only palette rather a range of greys more appropriate for the sector-blurring real world. For over two decades, Treasury, CBO, and others produced quality analyses of this problem, sometimes suggesting that the implicit subsidies to a GSE rather than the entire GSE be included in the budget. Political opposition prevented this modernization of budget concepts.

In great contrast, other scope issues have been resolved in favor of inclusiveness. When the Clinton administration proposed a new health care system, the $\mathrm{CBO}$ had to rule whether the new system should be reflected as part of the budget. It controversially recommended "yes" for the "health care alliances," even though some thought they were outside of the government 
orbit.(CBO, 1994; White, 1994; Seiler, 1994) Now, comprehensive health care reform has returned to the agenda, and $\mathrm{CBO}$ stated in a letter with the Joint Committee on Taxation to the sponsors of a bill to create the "Healthy Americans Private Insurance System" [emphasis supplied] (or HAPI!) that "most health insurance premiums that are now paid privately would flow through the Federal budget.”(CBO/JCT, 2008, p. 3)

Related logic was recently applied by $\mathrm{CBO}$ to another of our great challenges-global warming. The Lieberman-Warner Climate Security Act would create a Climate Change Credit Corporation, which would auction some emissions permits (the proceeds of which would be placed in a fund) and give away others. $\mathrm{CBO}$ made the fascinating ruling that these latter allowances should be recorded as revenues and outlays:

...the government is essential to the existence of the allowances and is responsible for their readily realizable monetary value through its enforcement. . .Therefore, CBO considers the distribution of such allowances at no charge to be functionally equivalent to distributing cash.(CBO, 2008, p.7)

The implications of this logic are immense, for it could convert all government actions which affect resource allocation and distribution into spending equivalents that would show in the budget. ${ }^{13}$ Like with health care, it would greatly expand the budget's scope, an important consequence in a political culture which is averse to "big government," even though the basis of this description is simplistic.

As with the link between macroeconomic policy-making and budgeting, there is no easy resolution to budget concepts problems. There are many that deserve attention, such as how to cost underfunded insurance programs or how to beat back pressure to record only the first-year 1998.

${ }^{13}$ For a discussion of the challenges to budgeting for regulatory policies, see Meyers, 
cost of a "lease" that is effectively a purchase. A commission which addressed such conceptual uncertainties and political problems, if it lived up to the reputation of the PCBC for using the best available analysis at the time, could help reduce the gimmickry that besets the process.(Meyers, 2004; Mathiasen, 2005)

Finally, returning to the case of health, it's well known that, despite the focus of some budget hawks on Medicare and Medicaid, the budget challenge of financing these programs is inseparable from the broader challenge of financing the growth of the economy's health care sector. Two decades ago, Herb Stein wrote a wonderful book which argued that this and similar realities in other sectors of the economy (e.g., the relationship between Social Security and private saving) requires thinking more broadly about policy than is permitted by the budget's current focus on the government's finances, to the point that we might attempt to "budget the GNP."(1989b) This insight may threaten those who worry that it implies a "national planning" that is taboo in the U.S., or that it would supplant the primacy of the (idealized) budget process-but Stein's suggestion is worth much additional consideration.

\section{Dysfunctional Jurisdictions for Priority-Setting}

The PCBC listed among the budget's multiple objectives that the budget "proposes an allocation of resources to serve national objectives, between the private and the public sectors, and within the public sector." Given the scope and scale of the federal government, such priority-setting is inherently a difficult task. Yet it is made nearly impossible by the obsolete categorization of the budget's elements and the corresponding but also obsolete jurisdictional claims on those elements. 
That obsolescence was ratified by the 1974 Act, which overlaid budget committees, a goal-setting budget resolution, and enforcement procedures on established authorizations and appropriations committees and processes. The Congressional committee structure, the legacy of almost two centuries of occasional political innovations and compromises, glorifies traditions.(Cogan,1994; Stewart, 1989) The result brings to mind the classic cartoon from $\underline{\text { The }}$ New Yorker that portrays a bureaucrat walking past an office door labeled "Bureau of Alcohol, Tobacco, and Firearms," and about to pass doors labeled "Bureau of Heroin, Snuff, and Dynamite," "Bureau of Caffeine, Cocaine, and Plutonium," and "Bureau of LSD, Cupcakes, and Anthrax." Similar misorganization exists in budgeting with health policy, where (in the House) Medicare is under the jurisdiction of Ways and Means, Medicaid is under Energy and Commerce, and most discretionary spending is under the Labor-HHS and Veterans subcommittees. But if health policy is now the greatest budget challenge we face, and if important aspects of health policy are so interrelated that they should be considered jointly, why not reorganize and create a health committee which could take primary responsibility for this topic? ${ }^{14}$

One argument against this course is that the traditional distinction between authorizations and appropriations properly separates the distinct activities of goal-setting and funding. Anyone who is familiar with the realities of Congress knows, however, that this distinction is more theoretical than practical. Appropriators routinely write "legislation" that by rule should be in

${ }^{14}$ When I have talked with legislators from other countries, they have always been befuddled that that the U.S. doesn't have a health committee. For examples of major reorganization proposals, see Rivlin, 1986 (collapse authorization and appropriations by sector); Cohen, 1982 and Tate, 1984 (Obey suggestion for “omnibus" budget). 
authorization bills. Sometimes they do this because the Congress does not enact authorizations for years after previous authorizations have expired. When the Congress does pass authorizations, it often does so after the appropriation is passed, even though the authorization is supposed to come first-e.g., for the sixth year in a row, the annual authorization for defense for FY08 was enacted after the appropriation. The authorizations which do pass usually include provisions that are indistinguishable in effect from appropriations limitations. Committee redundancy often generates confusingly overlapping directives to agencies. And it permits grossly inconsistent actions, such as the recent authorization of more spending for bridge safety at the same time that the authorizing and appropriations committees were fighting over how to respond to the reduction in highway trust fund receipts caused by increased gas prices.

Of course, one of the stimulants for the CBA was the growth of mandatory spending, which by definition mocks the logic of separated authorizations and appropriations. Budget enforcement procedures have since made huge distinctions between mandatory and discretionary spending. This has enabled some control within each sphere, but has also hindered reasonable tradeoffs between them. Nor does the process well evaluate or control tax preferences. ${ }^{15}$

Recall also the claims noted above for the FY09 budget resolution's allocations, in which Democrats said they were more generous than President Bush for selected accounts. Such claims could not be guaranteed because of the procedural inadequacy of the budget process. The budget resolution shows notional mandatory and discretionary subtotals for each budget function, with the statement of managers in the conference report then allocating the discretionary total to the Appropriations committees. But the Appropriations Committees make the real crosswalk to

${ }^{15}$ For the results, see the President's Advisory Panel on Federal Tax Reform, 2005. 
budget functions when they announce $302 \mathrm{~b}$ allocations. If the Congress wants the budget resolution to decide how to divide funds between guns and butter (or more specifically, the F-22 vs. the Milk Income Loss Contract program), it would have to force appropriators to conform $302 \mathrm{bs}$ to budget resolution totals, and also integrate mandatory spending allocations into this process.

The President's budget process has a greater claim to effective priority-setting because of its performance management orientation-though the U.S. is far behind countries which review sectors comprehensively, such as the U.K. U.S. budget preparation too infrequently uses "crosscuts" to compare similar but silo-separated programs, and generally fails to integrate tax preferences into budget reviews. At the agency and program levels, significant progress has been made due to concerted execution of the Government Performance and Results Act and the Program Assessment Rating Tool approaches. But Congress has more often received performance measures and program ratings with apathy or distaste than with approval.(Redburn, et. al., 2008) A reorganization which would better align committees and functional jurisdictions, thus making committees identifiably accountable for directing and overseeing performance, could help Congress come to its senses. Priority-setting in the budget process could also be encouraged by systematic reporting of economic, social, and environmental indicators.(Miringoff and Miringoff, 1999; GAO, 2004) Such reports could be especially helpful in framing the budget resolution, by providing verified information that would supplement the position-taking rhetoric that now dominates the debate.

Total skepticism about reorganization's prospects is understandable. Politically, it is exceptionally difficult because of committee seniority rights and electoral incentives.(Davidson 
and Oleszek, 1977; Arnold, 1998; Adler, 2002). Nor would it be a panacea, as rationalization of jurisdictions can't eliminate all overlaps, and some redundancy can be productive when turfing inspires innovation.(King, 1997). However, reorganization could permit the simplification of enforcement rules, and reduce the number of committee veto points which enable delay. And speaking of DeLay (that is, the former majority leader of the House), in 2005 he reorganized House Appropriations subcommittee jurisdictions to protect his favorite NASA from raids by veterans' advocates in the VA-HUD bill. While his motivation was not one of reform, his reorganization illustrated that committee jurisdictions are not immutable; it followed a homeland security reorganization, and was followed by another reorganization of the appropriations subcommittees when the Democrats gained control. The end result was a slightly more rational structure. Why not build on this progress-especially if the Democrats' electoral gains give them the power to make rule changes unilaterally?

\section{Aligning the Budget Process with Our Representative Institutions}

Governments occasionally replace dysfunctional rules with simpler, more effective ones (e.g., transportation deregulation). A budget process example is the "Gephardt rule" (for a while, the "Hastert rule"), which in the House automatically engrosses a bill to raise the public debt ceiling once the budget resolution is adopted. Since borrowing is the result of prior decisions to spend more than tax, this rule eliminates the need for a time-wasting symbolic vote, and also eliminates an opportunity for cheap blame generation by the minority (whether Republican or Democrat).

Much of the rational institutionalist and comparative literature on budgeting instead recommends that blame generation opportunities be increased. To simplify this logic, 
legislatures tend to universally distribute generous benefits to individual districts; controlling the resulting excesses requires delegating authority to an executive who can be held accountable by an electorate which understands that this person is solely responsible for budget totals.

Alternatively, particularly where the electoral system favors coalition over majority governments, the electorate should expect that coalition partners will develop binding contracts amongst themselves to produce and maintain prudent budgets.(von Hagen, et. al., 2002)

The 1921 Budget and Accounting Act was consistent with the logic of delegation to the executive. In the CBA, Congress moved the opposite way: it reasserted its power by assuming the responsibility of writing its own budget. But since Madison's design of "separated institutions sharing powers" was not junked--the president retains the veto power and the bully pulpit--the current system breaks down when for partisan reasons both branches act as if their respective budgets are unrelated.

Could this problem be reduced by modifying the contracting approach mentioned above for American institutions? One proposal of this type is to change the budget resolution from concurrent into joint form.(Meyers, 1990) If both branches planned to first agree on budget totals, and succeeded, they could find it easier to negotiate the details by the beginning of the fiscal year. The comparative evidence is that a two-step budget process produces more prudent results. Skeptics respond by predicting that agreement on totals would not precede agreement on all the details, and legislators often argue that a joint budget resolution would shift power to the president. On the other hand, if the Congress reached early agreement with the president, it would be less exposed to claims that it was imprudent. John Hilley's recent book (2008) on the negotiations leading to the 1997 Balanced Budget Act well illustrates many of the complexities 
involved with reaching bipartisan deals between the branches, but also points to the potential that such negotiations could be institutionalized.

While analysis of the joint resolution approach by a budget reform commission might reduce these instrumental uncertainties, its success would primarily depend on how national leaders felt obligated to behave-that is, on whether they can strengthen the budget norm of compromise. ${ }^{16}$ If they desire to do that, they might support the maintenance of this norm by establishing complementary procedures which would reduce opportunities for unrealistic creditclaiming and unfair blame-generation. Recalling the problem of Presidential candidates' dreamy promises, the U.S. could replicate Australia's "Charter of Budget Honesty" which requires the Treasury and Finance, if requested, to cost a candidates' election promises prior to a general election.(Wanna, et. al., 2000, p. 254; Australian Department of Finance, 2007) While the Tax Policy Center and US Budget Watch have produced useful calculations of the candidates' unaffordable promises, official estimates would receive more attention from the media and public, particularly if gimmickry could be controlled. For a more continuing public education, a popular budget report, like those released periodically in the past, could annually explain the basics of budget projections to citizens.

\section{$\underline{\text { Conclusion }}$}

In reaction to a proposed balanced budget constitutional amendment, CBO Director Rudy Penner said that "the process is not the problem; the problem is the problem." There is much truth to

${ }^{16}$ A similar opportunity has recently been described by the National War Powers Commission, which proposed new procedures to replace the ineffective War Powers Act (and arguably, to reinvigorate the "ex-Constitution". . .). 
this view; only by adopting policy changes will the desires of those who wish for a more sustainable budget be met. But a more realistic view of budget policy change understands that shifts in budget policies tend to coincide with changes to rules and norms. That is, no one (including Penner) really believes the extreme version of Penner's aphorism; after all, arguably Washington has the world's densest concentration of people who calculate the policy implications of rules. Most are trying to protect the status quo. If the result of their combined efforts is an unsustainable budget policy, then rules and associated norms will eventually need to change.

This article has suggested that the most intelligent way of reforming the budget process is to deliberate on the causes of and solutions to four major problems. This will require confronting intellectual challenges and even more daunting politics--or as the Temps sang it: "Great googalooga!" But unless these problems are addressed, a safe projection is that the ball of budget confusion will keep spinning. 


\section{$\underline{\text { References }}$}

Aaron, Henry, et. al., 2008. A Balanced Approach To Restoring Fiscal Responsibility," Center for Budget and Policy Priorities.

Adler, E. Scott, 2002. Why Congressional Reforms Fail: Reelection and the House Committee System. Chicago, IL: University of Chicago Press.

Arnold, Peri E., 1998. Making the Managerial Presidency: Comprehensive Reorganization Planning, 1905-1996. Lawrence, KS: University Press of Kansas.

Australian Department of Finance and Deregulation, 2007. "Charter of Budget Honesty: Costing Election Commitments."

http://www.finance.gov.au/Publications/charter-of-budget-honesty/docs/charter_of_budget_hone sty_2007.rtf

Baumann, David, 2008. “Purse Strings: A Tangled Mess.” CQ Weekly, May 19, 1336-1345.

Brookings Institutions/Heritage Foundation, 2008. Taking Back Our Fiscal Future. April.

Buckley, Christopher, 2007. Boomsday. N.Y.: Warner Books.

Cogan, John F., 1994. "The Dispersion of Spending Authority and Federal Budget Deficits." In Cogan, Timothy J. Muris and Allen Schick, The Budget Puzzle. Stanford, CA: Stanford University Press, 16-40.

Cohen, Richard E., 1982. "House Braces for Showdown over How It Should Package Its Annual Budget. National Journal. November 27, 2024-2026.

Committee for a Responsible Federal Budget, 2007. "Annual Conference," March 13. Accessed at: http://www.newamerica.net/events/2007/crfb conference

Congressional Budget Office, 1994. "An Analysis of the Administration's Health Proposal," February.

Congressional Budget Office, 2004. "Reforming the Federal Budget Process." Testimony of Director Douglas Holtz-Eakin before the Subcommittee on Legislative and Budget Process, Committee on Rules, U.S. House of Representatives, March 23.

Congressional Budget Office, 2008. "Cost Estimate for S. 2191, America's Climate Security Act of 2007." April 10.

Congressional Budget Office and Joint Committee on Taxation, 2008. "Letter to Senators 
Wyden and Bennett.” May 1.

Cooke, Maeve, 2000. "Five Arguments for Deliberative Democracy.” Political Studies, vol. 48, 947-969.

Davidson, Roger and Walter Oleszek, 1977. Congress Against Itself. Bloomington, IN: University of Indiana Press.

Dodd, Lawrence C., 1993. "Congress and the Politics of Renewal: Redressing the Crisis of Legitimation." In Congress Reconsidered, $5^{\text {th }}$ ed. Dodd and Bruce I. Oppenheimer, eds. Washington, D.C.: Congressional Quarterly Press.

Dolan, Chris J., John Frendreis, and Raymond Tatalovich, 2008. The Presidency and Economic Policy. Lanham, MD: Rowman and Littlefield.

Feldstein, Martin, 1994. American Economic Policy in the 1980s. Chicago, IL: University of Chicago Press.

Frankel, Jeffrey A., and Peter R. Orszag, eds. American Economic Policy in the 1990s. Cambridge, MA: MIT Press.

Freedberg, Sydney J., Jr., 2008. "Veterans Ask for an Advance.” National Journal, June 14, 4143.

Friel, Brian, 2008. "Dog Days.” National Journal, June 14, 22-28.

General Accounting Office, 2008a. Fiscal Year 2007 U.S. Government Financial Statements: Sustained Improvement in Financial Management is Crucial to Improving Accountability and Addressing the Long-Term Fiscal Challenge. June 26.

General Accounting Office, 2008b. Understanding Similarities and Differences between Accrual and Cash Deficits: Update for Fiscal Year 2007.

General Accounting Office, 2007. Accrual Budgeting Useful in Certain Areas but Does Not provide Sufficient Information for Reporting on Our Nation's Longer-Term Fiscal Challenge. December.

General Accounting Office, 2004. Informing Our Nation: Improving How to Understand and Assess the USA's Position and Progress. November.

Gilmour, John, 1995. Strategic Disagreement: Stalemate in American Politics. Pittsburgh, PA: University of Pittsburgh Press. 
Greenstein, Robert, 2008. Testimony before the House Committee on the Budget. June 24.

Gregg, Judd, 2008. "Statement on Pay-Go."

http://www.senate.gov/ budget/republican/pressarchive/2008-03-19Pay-GoStatement.pdf

Gutmann, Amy and Dennis Thompson, 1996. Democracy and Disagreement. Cambridge, MA: MIT Press.

Hamilton, Lee H., 2004. How Congress Works and Why You Should Care. Bloomington, IN: University of Indiana Press.

Heclo, Hugh, 2006. “Thinking Institutionally.” In R.A.W. Rhodes, Sarah A. Binder, and Bert A. Rockman, eds. The Oxford Handbook of Political Institutions. N.Y.: Oxford University Press, 731-742.

Hightower, Jim, 1997. There's Nothing in the Middle of the Road But Yellow Stripes and Dead Armadillos. N.Y.: Harper

Hilley, John L., 2008. The Challenge of Legislation: Bipartisanship in a Partisan World. Washington, D.C.: Brookings.

Hoagland, G. William, 2007. "A Comment on 'The Great Unraveling: Federal Budgeting, 19982006'.” Public Administration Review, vol. 67 (July), 618-623.

Hood, Christopher and Michael Jackson, 1991. Administrative Argument. Aldershot, UK:

Dartmouth.

Joyce, Philip G., 1996. "Congressional Budget Reform: The Unanticipated Implications for Federal Policy Making." Public Administration Review, vol. 56 (July), 317-325.

Joyce, Philip G., 2008. "Does More (or Even Better) Information Lead to Better Budgeting?: A New Perspective." Forthcoming in Journal of Policy Analysis and Management.

King, David C., 1997. Turf Wars: How Congressional Committees Claim Jurisdiction. Chicago, IL: University of Chicago Press.

Kingdon, John W., 1984. Agendas, Alternatives, and Public Policies. Boston: Little, Brown.

Kopke, Richard W., Geoffrey M.B. Tootell, and Robert K. Triest, eds., 2006. The Macroeconomics of Fiscal Policy. Cambridge, MA: MIT Press.

Kotlikoff, Laurence J. and Scott Burns, 2004. The Coming Generational Storm. Cambridge, MA: MIT Press. 
Kuttner, Robert, 2004. "Greenspan Speak: The Fed Chairman brings home the gold for hypocrisy." The American Prospect Online, May 14.

Mayer, Kenneth R., and David T. Canon, 1999. The Dysfunctional Congress? The Individual Roots of an Institutional Dilemma. Boulder, CO: Westview Press.

McCarty, Nolan, Keith T. Poole, and Howard Rosenthal, 2006. Polarized America: The Dance of Ideology and Unequal Riches. Cambridge, MA: MIT Press.

Mann, Thomas E., and Norman J. Ornstein, 2006. The Broken Branch: How Congress Is Failing America and How to Get It Back on Track. N.Y.: Oxford University Press.

Mathiasen, David, 2005. "This Fiscal Challenge: Federal Budget Concepts and Practices." Paper prepared for the Fiscal Futures Committee, National Academy of Public Administration, Washington, D.C.

Meyers, Roy T., 2004. “It's Time for A Second Commission on Budget Concepts." Presented at the Third Annual Congressional Budget Office Director's Conference, September 14.

Meyers, Roy T., 1998. "Regulatory Budgeting: A Bad Idea Whose Time Has Come?" Policy Sciences, vol 31 (December), 371-384.

Meyers, Roy T., 1997. "Late Appropriations and Government Shutdowns: Frequencies, Causes, Consequences, and Remedies." Public Budgeting and Finance, vol 17: Fall, 25-38.

Meyers, Roy T., 1996. "Is There a Key to the Normative Budgeting Lock?" Policy Sciences, vol. 29, 171-188.

Meyers, Roy T., 1990. "The Budget Resolution Should Be Law." Public Budgeting and Finance, vol. 10 (Fall), pp. 103-112.

Miringoff, Marc, and Marque-Luisa Miringoff, 1999. The Social health of the Nation: How America is Really Doing." N.Y.: Oxford University Press.

Office of Management and Budget, 2008. "Budget Reform Proposals." Analytical Perspectives, Budget of the U.S Government, Fiscal Year 2009, 213-225.

Orszag, Jonathan M., Peter R. Orszag, and Laura D. Tyson, 2002. “The Process of Economic Policy-Making During the Clinton Administration.” in Frankel and Orszag, 983-1027.

President's Advisory Panel on Federal Tax Reform, 2005. Simple, Fair and Pro-Growth: Proposals to Fix America's Tax System. Washington, D.C. (November). 
President's Commission on Budget Concepts, 1967. Report of the President's Commission on Budget Concepts. October.

Primo, David M., 2007. Rules and Restraint: Government Spending and the Design of Institutions. Chicago, IL: University of Chicago Press.

Redburn, F. Stevens, Robert J. Shea and Terry F. Buss, eds., 2008. Performance Management and Budgeting: How Governments Can Learn from Experience. Armonk, NY: M.E. Sharpe.

Riedl, Brian M., 2005. “What's Wrong with the Federal Budget Process.” Heritage Foundation Backgrounder number 1816, January 25.

Rivlin, Alice M., 1986. "The Need for a Better Budget Process." The Brookings Review. Summer, 3-10.

Rubin, Irene S., 2007. “The Great Unraveling: Federal Budgeting, 1998-2006.” Public Administration Review, vol. 67 (July), 608-617.

Rubin, Irene S., and Joanne Kelly, 2006. "Budget and Accounting Reforms," in Ewan Ferlie, Laurence E. Lynn Jr. and Christopher Pollitt, eds. Oxford Handbook of Public Management. N.Y.: Oxford University Press.

Seiler, Robin, 1994. "Applying Federal Budget Concepts to National Health Care Reform Proposals." Prepared for the 1994 Research Conference of the Association for Public Policy Analysis and Management, Chicago, IL: October 27-29.

Allen Schick, 2007. The Federal Budget: Politics, Policy, Process, $3^{\text {rd }}$ ed. Washington, D.C.: Brookings Institution.

Schick, Allen, 1990. The Capacity to Budget. Washington, D.C.: Urban Institute.

Schick, Allen, 1980. Congress and Money. Washington, D.C.: Urban Institute.

Schickler, Eric, 2001. Disjointed Pluralism: Institutional Innovation and the Development of the U.S. Congress. Princeton, NJ: Princeton University Press.

Schultze, Charles A., 1989. "Of Wolves, Termites, and Pussycats: Or, Why We Should Worry About the Budget Deficit." The Brookings Review, vol 7. (Summer), 26-33.

Smil, Vaclav, 2008. Global Catastrophes and Trends. Cambridge, MA: MIT Press.

Stein, Herbert, 1989a. "Governing the \$5 Trillion Economy." The Brookings Review, Spring, 16-23. 
Stein, Herbert, 1989b. Governing the \$5 Trillion Economy. NY: Oxford University Press.

Steuerle, C. Eugene, 2007. "Fiscal Policy from Kennedy to Reagan to G.W. Bush," in Kopke, et. al., 119-142.

Stewart, Charles III, 1989. Budget Reform Politics: The Design of the Appropriations Process in the House of Representatives, 1865-1921. N.Y.: Cambridge University Press.

Suskind, Ron, 2004. The Price of Loyalty. N.Y.: Simon and Schuster.

Taleb, Nassim Nicholas, 2007. The Black Swan. N.Y.: Random House.

Tate, Dale, 2004. "House Democrats to Consider Restructured Budget Process." CQ Weekly. December 1, 3033-3034.

von Hagen, Jurgen, Andrew Hughes Hallett and Rolf Strauch, 2002. "Budgetary Institutions for Sustainable Public Finances." In Marco Buti, Von Hagen and Carlos Martinez-Mongay. The Behavior of Fiscal Authorities. N.Y.: Palgrave, 94-112.

Wanna, John, Joanne Kelly, and John Forster, 2000. Managing Public Expenditure in Australia. St. Leonards, Australia: Allen and Unwin.

White, Joseph, 2001. False Alarm. Baltimore, MD: Johns Hopkins University Press.

White, Joseph, 1994. "When Should Health Care Be Included in Government Budgets?: A Comparative Perspective." Prepared for the 1994 Research Conference of the Association for Public Policy Analysis and Management, Chicago, IL: October 27-29.

Zelizer, Julian E., 2004. On Capitol Hill: The Struggle to Reform Congress and Its Consequences, 1948-2000. N.Y.: Cambridge University Press. 